\title{
Mind the gap? Business cycles and subjective well-being *
}

(Running title: Business cycles and subjective well-being)

\author{
Matti Hovi ${ }^{a}$ \\ Jani-Petri Laamanen ${ }^{b}$
}

2044 words

${ }^{*}$ We thank Jari Hännikäinen, Tuomas Malinen, Jari Vainiomäki and various seminar participants for comments. This work was supported by the OP-Pohjola Group Research Foundation and the Academy of Finland (project \#252369).

Disclosure statement: There are no potential conflicts of interest.

${ }^{a}$ School of Management, FI-33014 University of Tampere, Finland, E-mail: matti.hovi@staff.uta.fi, Tel. +358 503185975.

${ }^{b}$ Corresponding author. School of Management, FI-33014 University of Tampere, Finland, E-mail: jani-petri.laamanen@uta.fi, Tel. +358 3185993. 
We examine the relationship between output fluctuations and within-country variation in subjective well-being using country panels. We show that the deviation of output from trend, unlike trend growth, is positively associated with well-being. The explanatory power of the business cycle is found to be better than that of the level of output.

Keywords: Subjective well-being, GDP, Business cycle, Happiness, Life satisfaction

JEL codes: O11, I31, E32

\section{Introduction}

Analyses of international repeated cross-sections, such as those by Di Tella et al. (2003) and Stevenson and Wolfers (2008), point to a positive relationship between output and subjective well-being (SWB). However, the fact that Gross Domestic Product (GDP) is trending in virtually all countries whereas such a trend is not usually observed in SWB hints that a long-term relationship may not exist. Indeed, Easterlin (2013) shows that there is no systematic association between countries' long-run GDP growth rates and improvements in SWB. Discussions and analyses in Di Tella et al. (2003), Easterlin et al. (2010) and Easterlin (2013) point to the possibility that the deviation of output from its trend instead of output itself is associated with SWB. Our contribution is to examine this hypothesis in detail by using different measures of the relative output gap and regressing subjective well- 
being on each of them. We use panel data sets and model the within-country variation in SWB. The explanatory power of the output gap measures is compared to that of the log of GDP per capita.

\section{Data and methods}

We use Eurobarometer and combined World Values Survey/European Values Study (WVS) data. These data sets are the two most commonly used that include SWB questions and cover a long time span and various countries. The Eurobarometer data set contains observations from 34 European nations (including 24 OECD members) while the WVS sample contains observations from 78 nations (33 OECD members) around the world. In Eurobarometer, the longest time series start in 1973, and all series end in 2013. In the WVS, the time span is from 1981 to 2013. Our Eurobarometer observations are annual (no data in 1974) and there are on average 6 years between observations in our WVS data set. The real GDP per capita data are gathered from the Penn World Tables. We extend the Penn World Tables data through 2016 using growth rates calculated from the IMF World Economic Outlook (April 2015) data and forecasts.

The regression equations are of the form:

$$
s_{i t}=\alpha_{i}+\beta x_{i t}+\epsilon_{i t},
$$


where $s_{i t}$ is the population-weighted average life satisfaction or happiness in country $i$ in year $t .^{1,2}$ The explanatory variable $x_{i t}$ is an output gap measure or the log of real GDP per capita, $\alpha_{i}$ is a country fixed effect and $\epsilon_{i t}$ is the error term. We estimate the country-specific relative output gap using linear detrending, quadratic detrending, Baxter-King filtering and HodrickPrescott (HP) filtering with three alternative, commonly used smoothing parameters of $6.25,100$ and $400 .^{3}$ The period selected for the detrending is 1970-2016. All models are estimated with and without year fixed effects. We also estimate models which include both the cycle component and the extracted trend component. Countries and years with only one observation are excluded because their values would be completely captured by the fixed effects.

\section{Results and discussion}

The estimated $\beta$ coefficients and within $R^{2}$ values are reported in Table 1 . Each cell in the table accounts for one model. The coefficient estimate from the model with the highest within $\mathrm{R}^{2}$ in each column is underlined.

\footnotetext{
${ }^{1}$ Although we use WVS happiness data, we acknowledge its deficiencies pointed out by e.g. Easterlin et al. (2010).

${ }^{2}$ Examining the properties of the continuous Eurobarometer time series further supports the idea of regressing SWB on a detrended variable. Pesaran's (2007) test for crosssectionally dependent panels reveals that unit roots in the SWB panel can be rejected. The lag length in the augmented Dickey-Fuller test for each country is chosen according to the Bayesian Information Criterion. The results are available upon request.

${ }^{3}$ We also tried economic growth, but its explanatory power was comparatively low. In additional analyses, we reached the same conclusions by using IMF and OECD output gap measures (for the smaller samples for which they are available).
} 
[Table 1 about here]

The results show that business cycles are positively associated with SWB. In only one out of the 36 models with a cycle variable, the regressor is not statistically significant at the $5 \%$ level. The cycle variable with the best explanatory power is either deviation from the linear trend or deviation from the quadratic trend. Judging from the magnitudes of the estimates, taking into account the different scale of WVS life satisfaction, the cyclical variables seem to be about as important, and sometimes more important, in the WVS sample as in the Eurobarometer sample. At this point, note that the cyclical variables also capture longer term fluctuations other than business cycles. Visually, such fluctuations are prevalent in the output time series of relatively many WVS countries (especially developing and transition countries). Consistency of our results indicates that these fluctuations are associated with similar fluctuations in SWB. For an example of the economic significance of the estimated associations, consider column 1b. The coefficient of the bestfitting model (0.64) implies that an increase in the output gap measure by one SD increases life satisfaction by almost one half of a standard deviation. ${ }^{4}$

Comparing the explanatory power of the cycle variables to that of the GDP variable, we find that in none of the columns the model with the GDP variable provides the best fit. Although log of GDP per capita yields a comparatively poor fit, it has a positive and statistically significant coefficient

\footnotetext{
${ }^{4} \mathrm{SDs}$ are calculated using within-country variation.
} 
in most cases. Under an assumption that the business cycle instead of output is what matters for SWB, this kind of results can be found if the share of cyclical variation in the variation of the GDP variable (conditional on the fixed effects) is sufficiently large. To check whether we have ignored a potentially important association between trend growth and SWB growth, we re-estimated the models with a cyclical variable and included the extracted trend component as an additional regressor. This also serves as a robustness check, because the correlations between the cycle variables and corresponding trend variables are not always zero and there might, thus, be omitted variable bias in our estimates. ${ }^{5}$ The results are presented in Table 2.

[Table 2 about here]

Among the best-fitting models, the coefficient for the trend component is statistically significantly positive only in the model of WVS happiness without year fixed effects and becomes negative and significant when year fixed effects are included. It should be noted that we are not the first to observe negative assocations of output variables with SWB in the WVS data (see Opfinger, 2016). In general, our findings on trend growth's association with SWB are in line with those by Easterlin et al. (2010) and Easterlin (2013). There are only minor changes in the coefficients of the cyclical variables in the

\footnotetext{
${ }^{5}$ Nonzero correlations are due to different periods for detrending and estimation and because some of the detrending techniques do not require the cycle component and the trend component to be uncorrelated.
} 
best fitting models while the statistical significances remain unchanged. This confirms the robustness of our results on the association between business cycles and subjective well-being.

\section{Conclusions}

Deviation of output from its long-term trend, unlike trend growth, has explanatory power for subjective well-being within countries over time. The explanatory power is better than that of output. This reflects the fact that output series trend upward whereas such a trend is usually absent from time series of subjective well-being.

\section{References}

Easterlin, R., Mcvey, L., Switek, M., Sawangfa, O., Zweig, J., 2010. "The Happiness-Income Paradox Revisited." Proceedings of the National Academy of Sciences 107(52), 22463-22468. doi:10.1073/pnas.1015962107.

Easterlin, R., 2013. "Happiness, Growth, and Public Policy." Economic Inquiry 51(1), 1-15. doi:10.1111/j.1465-7295.2012.00505.x.

Di Tella, R., MacCulloch, R., Oswald, A., 2003. "The Macroeconomics of Happiness." Review of Economics and Statistics 85(4), 809-827. doi:10.1162/003465303772815745 
Opfinger, M., 2016. "The Easterlin Paradox Worldwide." Applied Economics Letters 23(2), 85-88. doi:10.1080/13504851.2015.1051650.

Pesaran, M., 2007. "A Simple Panel Unit Root Test in the Presence of CrossSection Dependence." Journal of Applied Econometrics 22(2), 265-312. doi:10.1002/jae.951.

Stevenson, B., Wolfers, J., 2008. "Economic Growth and Subjective WellBeing: Reassessing the Easterlin Paradox." Brookings Papers on Economic Activity, Spring, 1-102. doi:10.1353/eca.0.0001. 


\section{Table 1. Models of subjective well-being}

\begin{tabular}{|c|c|c|c|c|c|c|}
\hline \multirow[t]{2}{*}{ Dependent variable (scale): } & \multicolumn{2}{|c|}{ EB satisfaction (1-4) } & \multicolumn{2}{|c|}{ WVS satisfaction (1-10) } & \multicolumn{2}{|c|}{ "WVS happiness (1-4) } \\
\hline & (1a) & $(1 \mathrm{~b})$ & $(1 \mathrm{c})$ & $(1 \mathrm{~d})$ & $(1 \mathrm{e})$ & $(1 \mathrm{f})$ \\
\hline \multicolumn{7}{|l|}{ Explanatory variable } \\
\hline \multirow[t]{2}{*}{$\overline{\text { Baxter-King Cycle }}$} & $1.09 * * *$ & $1.20 * * *$ & $9.81^{* * *}$ & $6.97^{* * *}$ & $1.72^{* * *}$ & $1.27^{* *}$ \\
\hline & $(0.22)$ & $(0.24)$ & $(1.34)$ & $(1.67)$ & $(0.39)$ & $(0.57)$ \\
\hline $\mathrm{R}^{2}$ & 0.049 & 0.215 & 0.279 & 0.534 & 0.113 & 0.419 \\
\hline \multirow[t]{2}{*}{ HP Cycle (6.25) } & $0.97 * * *$ & $1.04^{* * *}$ & $8.06^{* * *}$ & $4.73^{* * *}$ & $1.39 * * *$ & 0.90 \\
\hline & $(0.20)$ & $(0.21)$ & $(1.45)$ & $(1.57)$ & $(0.46)$ & $(0.61)$ \\
\hline $\mathrm{R}^{2}$ & 0.041 & 0.210 & 0.168 & 0.497 & 0.066 & 0.404 \\
\hline \multirow[t]{2}{*}{ HP Cycle (100) } & $0.70^{* * *}$ & $0.58 * * *$ & $5.45^{* * *}$ & $3.51^{* * *}$ & $0.90^{* * *} *$ & $0.65^{* *}$ \\
\hline & $(0.16)$ & $(0.18)$ & $(0.70)$ & $(0.83)$ & $(0.20)$ & $(0.26)$ \\
\hline $\mathrm{R}^{2}$ & 0.059 & 0.208 & 0.322 & 0.540 & 0.115 & 0.422 \\
\hline \multirow[t]{2}{*}{ HP Cycle (400) } & $0.63^{* * *}$ & $0.59 * * *$ & $4.01^{* * *}$ & $2.75^{* * *}$ & $0.69^{* * *}$ & $0.51^{* * *}$ \\
\hline & $(0.13)$ & $(0.16)$ & $(0.51)$ & $(0.57)$ & $(0.13)$ & $(0.17)$ \\
\hline $\mathrm{R}^{2}$ & 0.073 & 0.218 & 0.376 & 0.564 & 0.145 & 0.433 \\
\hline \multirow[t]{2}{*}{ Cycle (quadratic trend) } & $0.47^{* * *}$ & $0.46^{* * *}$ & $\underline{3.01}^{* * *}$ & $\underline{2.14}^{* * *}$ & $0.53 * * *$ & $0.36 * * *$ \\
\hline & $(0.08)$ & $(0.12)$ & $(\overline{0.36})$ & $(\overline{0.40})$ & $(0.09)$ & $(0.11)$ \\
\hline $\mathrm{R}^{2}$ & 0.087 & 0.229 & 0.420 & 0.587 & 0.168 & 0.434 \\
\hline \multirow[t]{2}{*}{ Cycle (linear trend) } & $\underline{0.55^{* * *}}$ & $\underline{0.64^{* * *}}$ & $2.66^{* * *}$ & $1.84^{* * *}$ & $\underline{0.52^{* * *}}$ & $\underline{0.36} \underline{6}^{* * *}$ \\
\hline & $(\overline{0.12})$ & $(\overline{0.15})$ & $(0.38)$ & $(0.41)$ & $(\overline{0.09})$ & $(\overline{0.09})$ \\
\hline $\mathrm{R}^{2}$ & 0.149 & 0.293 & 0.394 & 0.580 & 0.194 & 0.448 \\
\hline \multirow{2}{*}{$\ln (\mathrm{GDP} p c)$} & $0.11^{* * *}$ & $0.21^{*}$ & $0.84^{* * *}$ & $0.60^{*}$ & $0.22^{* * *}$ & 0.06 \\
\hline & $(0.04)$ & $(0.11)$ & $(0.20)$ & $(0.33)$ & $(0.05)$ & $(0.08)$ \\
\hline $\mathrm{R}^{2}$ & 0.058 & 0.223 & 0.234 & 0.500 & 0.189 & 0.393 \\
\hline$\overline{\text { Year FEs }}$ & $\mathrm{No}$ & Yes & $\mathrm{No}$ & Yes & $\mathrm{No}$ & Yes \\
\hline Obs. & 654 & 654 & 291 & 291 & 290 & 290 \\
\hline Countries & 34 & 34 & 78 & 78 & 78 & 78 \\
\hline
\end{tabular}


Table 2. Models of subjective well-being including the trend component

\begin{tabular}{|c|c|c|c|c|c|c|c|c|c|c|c|}
\hline \multirow{2}{*}{$\begin{array}{l}\text { Dependent variable (scale): } \\
\text { Explanatory variable: }\end{array}$} & \multicolumn{4}{|c|}{ EB satisfaction (1-4) } & \multicolumn{3}{|c|}{ WVS satisfaction (1-10) } & \multicolumn{4}{|c|}{ WVS happiness (1-4) } \\
\hline & Cycle & Trend & Cycle & Trend & Cycle Trend & Cycle & Trend & Cycle & Trend & Cycle & Trend \\
\hline Baxter-King & $\begin{array}{l}1.01^{* * *} \\
(0.22)\end{array}$ & $\begin{array}{l}0.09 * * \\
(0.04)\end{array}$ & $\begin{array}{l}1.04^{* * *} \\
(0.24)\end{array}$ & $\begin{array}{l}0.17 \\
(0.11)\end{array}$ & $\begin{array}{ll}7.69 * * * & 0.52^{* * * *} \\
(1.18) & (0.17)\end{array}$ & $\begin{array}{l}6.25^{* * *} \\
(1.66)\end{array}$ & $\begin{array}{c}0.27 \\
(0.32)\end{array}$ & $\begin{array}{l}1.03^{* *} \\
(0.44)\end{array}$ & $\begin{array}{l}0.18^{* * *} \\
(0.05)\end{array}$ & $\begin{array}{l}1.32^{* *} \\
(0.63)\end{array}$ & $\begin{array}{r}-0.02 \\
(0.09)\end{array}$ \\
\hline $\mathrm{R}^{2}$ & & 0.093 & & 0.235 & 0.349 & & 0.539 & & 0.210 & & 0.419 \\
\hline HP (6.25) & $\begin{array}{l}0.94 * * * \\
(0.20)\end{array}$ & $\begin{array}{l}0.10 * * * \\
(0.04)\end{array}$ & $\begin{array}{l}0.96 * * * \\
(0.22)\end{array}$ & $\begin{array}{l}0.18 \\
(0.11)\end{array}$ & $\begin{array}{ll}6.26^{* * *} & 0.68^{* * *} \\
(1.08) & (0.18)\end{array}$ & $\begin{array}{l}4.07 * * * \\
(1.47)\end{array}$ & $\begin{array}{c}0.47 \\
(0.32)\end{array}$ & $\begin{array}{l}0.91^{* *} \\
(0.45)\end{array}$ & $\begin{array}{l}0.20 * * * \\
(0.05)\end{array}$ & $\begin{array}{c}0.86 \\
(0.63)\end{array}$ & $\begin{array}{r}0.03 \\
(0.09)\end{array}$ \\
\hline $\mathrm{R}^{2}$ & & 0.089 & & 0.234 & 0.305 & & 0.516 & & 0.204 & & 0.405 \\
\hline HP (100) & $\begin{array}{l}0.70^{* * *} \\
(0.15)\end{array}$ & $\begin{array}{l}0.09 * * \\
(0.04)\end{array}$ & $\begin{array}{l}0.56^{* * * *} \\
(0.16)\end{array}$ & $\begin{array}{l}0.18 \\
(0.12)\end{array}$ & $\begin{array}{ll}4.57^{* * *} & 0.42^{* *} \\
(0.75) & (0.17)\end{array}$ & $\begin{array}{l}3.34 * * * \\
(0.89)\end{array}$ & $\begin{array}{c}0.14 \\
(0.34)\end{array}$ & $\begin{array}{l}0.54^{* *} \\
(0.24)\end{array}$ & $\begin{array}{l}0.18^{* * *} \\
(0.06)\end{array}$ & $\begin{array}{l}0.72^{* *} \\
(0.29)\end{array}$ & $\begin{array}{l}-0.06 \\
(0.09)\end{array}$ \\
\hline $\mathrm{R}^{2}$ & & 0.102 & & 0.230 & 0.361 & & 0.541 & & 0.201 & & 0.425 \\
\hline HP (400) & $\begin{array}{l}0.61^{* * *} \\
(0.12)\end{array}$ & $\begin{array}{l}0.08^{* *} \\
(0.04)\end{array}$ & $\begin{array}{l}0.55^{* * *} \\
(0.14)\end{array}$ & $\begin{array}{l}0.16 \\
(0.12)\end{array}$ & $\begin{array}{lc}3.63^{* * *} & 0.28^{*} \\
(0.55) & (0.16)\end{array}$ & $\begin{array}{l}2.79 * * * \\
(0.59)\end{array}$ & $\begin{array}{l}-0.06 \\
(0.33)\end{array}$ & $\begin{array}{l}0.48^{* * *} \\
(0.16)\end{array}$ & $\begin{array}{l}0.16^{* * *} \\
(0.06)\end{array}$ & $\begin{array}{l}0.57^{* * * *} \\
(0.17)\end{array}$ & $\begin{array}{r}-0.11 \\
(0.08)\end{array}$ \\
\hline $\mathrm{R}^{2}$ & & 0.107 & & 0.233 & 0.391 & & 0.564 & & 0.207 & & 0.440 \\
\hline Quadratic & $\begin{array}{l}0.44^{* * *} \\
(0.08)\end{array}$ & $\begin{array}{c}0.07 \\
(0.05)\end{array}$ & $\begin{array}{l}0.44^{* * *} \\
(0.11)\end{array}$ & $\begin{array}{c}0.12 \\
(0.14)\end{array}$ & $\underline{\left(\frac{2.88}{0.38}\right)}^{* * *} \quad \frac{0.16}{(0.15)}$ & $\left.\underline{2.17}^{* * 3 *}\right)$ & $\frac{-0.19}{(0.26)}$ & $\begin{array}{l}0.42^{* * *} \\
(0.11)\end{array}$ & $\begin{array}{l}0.14^{* * * *} \\
(0.05)\end{array}$ & $\begin{array}{l}0.37^{* * * *} \\
(0.10)\end{array}$ & $\begin{array}{l}-0.11 \\
(0.07)\end{array}$ \\
\hline $\mathrm{R}^{2}$ & & 0.105 & & 0.236 & 0.424 & & 0.589 & & 0.214 & & 0.442 \\
\hline Linear & $\frac{0.55^{* * *}}{(0.13)}$ & $\frac{0.05}{(0.04)}$ & $\frac{0.65}{(0.16)}$ & $\frac{-0.05}{(0.14)}$ & $\begin{array}{ll}2.54^{* * *} & 0.19 \\
(0.40) & (0.19)\end{array}$ & $\begin{array}{l}1.87^{* * *} \\
(0.42)\end{array}$ & $\begin{array}{l}-0.27 \\
(0.35)\end{array}$ & $\frac{0.44}{(0.10)}^{* * *}$ & $\underline{0.13}^{*}{ }^{*} * 6$ & $\left.\underline{0.38}^{* * 09}\right)^{* *}$ & ${\frac{-0.18^{* *}}{(0.07)}}^{*}$ \\
\hline $\mathrm{R}^{2}$ & & 0.161 & & 0.294 & 0.400 & & 0.584 & & 0.228 & & 0.467 \\
\hline Year FEs & No & & Yes & & No & Yes & & No & & $\overline{\mathrm{Ye}}$ & es \\
\hline Obs. & 654 & & 654 & & 291 & 291 & & 290 & & 29 & 0 \\
\hline Countries & 34 & & 34 & & 78 & 78 & & 78 & & $7 \varepsilon$ & 8 \\
\hline
\end{tabular}

